\title{
Bladder Cancer pT4a TNM Finding v8
}

National Cancer Institute

\section{Source}

National Cancer Institute. Bladder Cancer pT 4a TNM Finding v8. NCI Thesaurus. Code C140405.

Bladder cancer with extravesical tumor invading directly into prostatic stroma, uterus, vagina. (from AJCC 8th Ed.) 